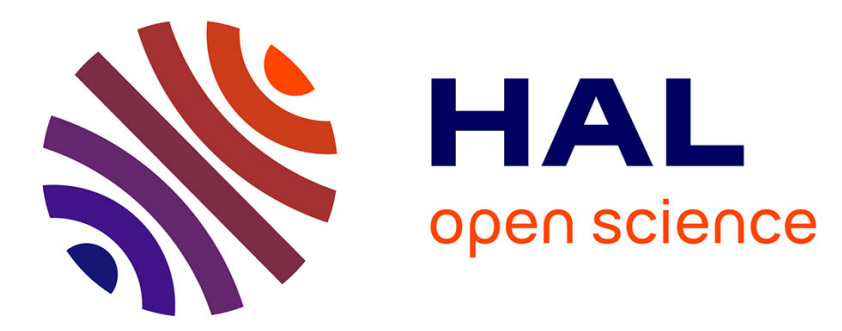

\title{
A more consistent method for extracting and amplifying DNA from bee wings
}

Elaine Gould, Michelle Taylor, Selena Holmes

\section{To cite this version:}

Elaine Gould, Michelle Taylor, Selena Holmes. A more consistent method for extracting and amplifying DNA from bee wings. Apidologie, 2011, 42 (6), pp.721-727. 10.1007/s13592-011-0077-x . hal01003614

\section{HAL Id: hal-01003614 https://hal.science/hal-01003614}

Submitted on 1 Jan 2011

HAL is a multi-disciplinary open access archive for the deposit and dissemination of scientific research documents, whether they are published or not. The documents may come from teaching and research institutions in France or abroad, or from public or private research centers.
L'archive ouverte pluridisciplinaire HAL, est destinée au dépôt et à la diffusion de documents scientifiques de niveau recherche, publiés ou non, émanant des établissements d'enseignement et de recherche français ou étrangers, des laboratoires publics ou privés. 


\title{
A more consistent method for extracting and amplifying DNA from bee wings
}

\author{
Elaine M. Gould, Michelle A. TAYLOR, Selena J. Holmes \\ The New Zealand Institute for Plant and Food Research, Private Bag 3230, Waikato Mail Centre, Hamilton 3240, \\ New Zealand
}

Received 23 November 2010 - Revised 7 March 2011 - Accepted 8 March 2011

\begin{abstract}
Non-lethal sampling of DNA from honeybees is commonly required for genotyping certain behavioural traits required for breeding. One method is to use wing clippings. However, the sample is very small, and the extraction process can be difficult, resulting in low polymerase chain reaction (PCR) amplification. Here, we describe an improved method for extracting DNA from bee wings using a commercially available kit that uses bashing beads to physically break up the wings. It enabled $93 \%$ to $100 \%$ PCR amplification when amplified using microsatellite or mitochondrial primers. The results were compared with the Chelex ${ }^{\circledR} 100$ extraction method, which, in this laboratory, resulted in only between $56 \%$ and $72 \%$ amplification in subsequent PCR.
\end{abstract}

DNA / bee wing / PCR / bashing beads / Chelex ${ }^{\circledR} 100$

\section{INTRODUCTION}

In recent years, honeybee (Apis mellifera) colonies have been in decline for a number of reasons: viral infections, Nosema ceranae infections (Higes et al. 2008), colony collapse disorder (van Engelsdorp et al. 2009) and Varroa destructor parasitism (Garedew et al. 2004), which also renders the bees more prone to the lethal effects of viral infections (BowenWalker et al. 1999). In response to these problems, there has been a drive in research to find ways of controlling Varroa by breeding bees that physically remove the mites by a behaviour called 'Varroa-sensitive hygiene' (VSH) (Harbo and Harris 2005; Harris 2008). This breeding requires knowledge of the highly variable regions in the bee genome that can be identified and linked to certain behaviours

Corresponding author: E.M. Gould, elaine.gould@plantandfood.co.nz

Manuscript editor: Klaus Hartfelder within populations and individuals. Microsatellites are short repeat sequences of DNA, e.g. CACACA, with the number of the repeats varying between individuals, thus are useful markers for breeding studies. There are 550 microsatellite markers known in bees (Solignac et al. 2003) which can prove useful for genotyping certain behaviours, such as fanning behaviour (Su et al. 2007). However, for DNA analysis to be useful for breeding programmes, the queen bees must remain alive.

Non-lethal sampling of genetic material, however, poses a challenge as DNA can only be non-lethally extracted from the wing, thus providing only a small sample of tissue and DNA. One method that is commonly used to extract DNA from bee wings and other bee parts is using the chelating resin Chelex ${ }^{\circledR} 100$ (Franck et al. 1999, 2000; Châline et al. 2004; Gregory and Rinderer 2004; Su et al. 2007; Pérez-Sato et al. 2009). However, the subsequent polymerase chain reaction (PCR) amplification is variable; Châline et al. (2004) 
reported success rates between $70 \%$ and $97.5 \%$ using bee wings, depending upon the amount of wing tissue, its treatment prior to extraction and which loci were amplified. This can pose a frustrating problem if a bee, particularly queen bee, is required for further breeding, but cannot be accurately genotyped.

The purpose of this study was to find a more reliable method for DNA extraction from bee wings, producing DNA of sufficient quality to allow subsequent amplification via PCRs. These bee-wing extraction methods were also compared with a commercially available kit that extracted $100 \%$ of the DNA from bee heads and subsequent PCR (positive control) (Promega Wizard $^{\circledR}$ Genomic DNA Purification Kit). Three primer pairs were used-two targeting microsatellite loci and one mitochondrial gene.

\section{MATERIALS AND METHODS}

\subsection{Honeybees}

Worker honeybees (A. mellifera) were collected from colonies kept at Plant and Food Research, Ruakura, Waikato, New Zealand. The bees were stored at $-80^{\circ} \mathrm{C}$ until required.

\subsection{DNA extractions}

DNA was extracted from the heads of 26 bees using the Promega Wizard ${ }^{\circledR}$ Genomic DNA Purification Kit (cat. no. A1120, in vitro, New Zealand), following the manufacturer's protocol for animal tissue. At the end of the extraction, the DNA pellet was resuspended in $100 \mu \mathrm{l}$ of DNA rehydration solution and left overnight at $4{ }^{\circ} \mathrm{C}$. The samples were stored at $-20^{\circ} \mathrm{C}$. One $\mu$ of sample was used in subsequent PCRs.

Using wings from the same bees as above, DNA was extracted from the wings using two methods. The first method was the Chelex ${ }^{\circledR} 100$ (cat. no. 1421253, BioRad Laboratories, New Zealand) method (Walsh et al. 1991) for bee wings previously described by Châline et al. (2004) with the variation of Franck et al. (1999). A small section of bee wing was placed in a microcentrifuge tube. The tube and wing were dropped into liquid nitrogen for $2-3 \mathrm{~min}$ before crushing most of the tissue with a sterile,
DNase-free pestle. A $10 \%$ Chelex solution was made using sterile water. The mixture was continuously stirred using a magnetic stirrer whilst the solution was added to the bee wing to maintain the Chelex beads in suspension. Then, $120 \mu \mathrm{g}$ of proteinase $\mathrm{K}$ (cat. no. 161519 , Roche, New Zealand) in $50 \mu \mathrm{l}$ of $10 \%$ Chelex ${ }^{\circledR} 100$ solution was added to each wing. The samples were digested overnight at $56^{\circ} \mathrm{C}$. The samples were vortexed for $10 \mathrm{~s}$ then boiled at $100^{\circ}$ $\mathrm{C}$ for $15 \mathrm{~min}$. The samples were vortexed for another $10 \mathrm{~s}$ then centrifuged at $8,000 \times \mathrm{g}$ for $3 \mathrm{~min}$. Where practical, DNA was amplified as soon as possible after the extraction using one primer pair. The samples were stored at $-20^{\circ} \mathrm{C}$. Before further sample was amplified in other PCRs, frozen samples were allowed to thaw, vortexed for $10 \mathrm{~s}$ and centrifuged at $8,000 \times g$ for $3 \mathrm{~min}$. Five microlitres of the supernatant was used in subsequent PCRs. Failed PCR amplifications were repeated using different magnesium concentrations (1.5 to $5 \mathrm{mM}$ ), fresh dNTPs and different polymerase enzymes.

For the second method, DNA was extracted from 26 bee wings using the Zymo Research ZR Insect/Tissue DNA Kit-5 ${ }^{\text {TM }}$ (cat. no. D6015, Ngaio Diagnostics, New Zealand) (referred to herein as ZR bashing bead method, ZRBB). A small section of bee wing was placed in a ZR Bashing Bead ${ }^{\mathrm{TM}}$ lysis tube, $750 \mu \mathrm{l}$ of lysis solution added and the cap sealed tightly. The tube was placed in a 2-ml tube holder of a FastPrep ${ }^{\circledR}-24$ Instrument (MP Biomedicals) and processed twice at $6 \mathrm{~m} / \mathrm{s}$ for $40 \mathrm{~s}$. The DNA was extracted following the kit protocol. The DNA was resuspended in $40 \mu \mathrm{l}$ of elution buffer and was stored at $-20^{\circ} \mathrm{C}$. Five microlitres of the supernatant was used in subsequent PCRs.

\subsection{Measurement of quantity and quality of DNA}

One microlitre of each DNA sample from each extraction method was placed on the pedestal of a NanoDrop 2000c Spectrophotometer (Thermo Scientific) to measure quantity and determine quality of each sample.

\subsection{PCR amplification}

The DNA was amplified using three sets of primers designed for highly variable regions within 
the honeybee genome: COI-COII mitochondrial intergenic region and microsatellites A113 and A107. All PCRs were performed using $P f x$ polymerase (cat no. 11708-013, Invitrogen, New Zealand), following the kit protocol. All primers (supplied by Invitrogen, New Zealand) were at a final concentration of $1 \mu \mathrm{M}$. The primer sequences, the annealing temperature and $\mathrm{Mg}+$ concentration are described in Table I. All of the PCRs were performed using a positive (one-head DNA sample that had been previously amplified) and negative controls (water, TE buffer and master mix only).

\subsection{Gel electrophoresis}

The PCR products amplified with the COI-COII primers were electrophoresed on $1 \%$ agarose (cat. no. 15510-027, Gibco BRL, Invitrogen, New Zealand) gel made with $0.5 \times$ TBE and stained with $\mathrm{Sybr}^{\circledR}$ Safe (cat no. S33102, Invitrogen, New Zealand). The microsatellite PCR products were separated on $6 \%$ PAGE gel and electrophoresed in $1 \times \mathrm{TBE}$ at $9 \mathrm{~V} / \mathrm{cm}$. Samples were size-compared with two DNA ladders: 10-bp ladder (cat. no. 10821-015, Invitrogen, New Zealand) and 100-bp ladder (Fermentas GeneRuler ${ }^{\mathrm{TM}}$ cat. no. SM0241, Global Science, New Zealand). After electrophoresis, the PAGE gel was soaked in $1 \times$ TBE plus ethidium bromide for 15-20 min. All gels were visualised under UV on a Gel Doc (BioRad Laboratories), using the Quantity One programme.

\section{RESULTS}

DNA was extracted from all samples using the three different techniques. However, the quantity and quality of the samples varied.
The DNA extracted from the head using the Promega extraction method gave the largest quantity and best quality DNA. The DNA extracted using the Chelex ${ }^{\circledR} 100$ method resulted in a larger quantity of DNA from wing tissue, compared with the ZRBB method, but the quality was poorer, with no sample giving a ratio between 1.8 and 2.2. Table II shows the quantity and quality data for each extraction method.

The amplification of the DNA samples from all the extraction methods is shown in Table III. All of the positive control samples amplified successfully. The TE buffer and master mix negative controls were always 'blank' when observed on the gel. However, the water controls consistently gave bands when amplified with the microsatellite primers (Figure 1). Re-ordering fresh primer pairs and reconstituting them in fresh TE buffer, changing primer concentration, changing annealing temperature and magnesium concentration did not remove these bands.

The COI-COII primers successfully amplified all of the head DNA samples. However, only $72 \%$ extracted using Chelex ${ }^{\circledR} 100$ were successfully amplified. The COI-COII primers amplified 25/26 of the ZRBB wing samples; the one sample that did not amplify did not have enough DNA (less than $5 \mu$ l) for the PCR. The microsatellite primers A113 and A107 showed some slight variation in amplification success using DNA extracted with the ZRBB kit; the reason for the two failed amplifications with A113 is unclear. The microsatellite primers A113 and A107 had much lower amplification

Table I. Polymerase chain reaction conditions for the three primers.

\begin{tabular}{llccl}
\hline Gene/loci & Primers & $\mathrm{Mg}+(\mathrm{mM})$ & Anneal $\left({ }^{\circ} \mathrm{C}\right)$ & References \\
\hline COI-COII & $\begin{array}{l}\text { 5'-GGCAGAATAAGTGCATTG } \\
\text { 5'-CAATATCATTGATGACC }\end{array}$ & 1 & 55 & Sušnik et al. (2004) \\
A113 & $\begin{array}{l}\text { 5'-CTCGAATCGTGGCGTCC } \\
\text { 5'-CCTGTATTTTGCAACCTCGC }\end{array}$ & 1.2 & 60 & Franck et al. (2000) \\
A107 & $\begin{array}{l}\text { 5'-CCGTGGGAGGTTTATTGTCG } \\
\text { 5'-CCTTCGTAACGGATGACACC }\end{array}$ & 1.2 & 50 & Gregory and Rinderer (2004) \\
&
\end{tabular}


Table II. The quantity and quality (260:280 ratio) of DNA extracted using the three different methods.

Extraction method

Chelex $^{\circledR} 100$

Promega

ZRBB
Average quantity (ng/ $\mu \mathrm{l})$ [range]

$18.8[9.3-75]$

$305.4[19.8-1646.4]$

$3.9[1.4-8.3]$

Percentage samples within 1.8-2.2 [range]

The ranges are given in square brackets

${ }^{\text {a }}$ Six of the samples had ratios above 2.2

success using Chelex ${ }^{\circledR} 100$ extracted DNA, particularly A107, which only resulted in $56 \%$ amplification success. PCR amplification with A113 was lower with all three extraction methods compared with the other two primer pairs.

Figure 1 is an example of a microsatellite amplification electrophoresed on a $6 \%$ PAGE gel. It shows the amplification of eight bee wing samples extracted using ZRBB kit amplified with primer A113.

\section{DISCUSSION}

This study describes a consistent and efficient method of extracting DNA from bee wings, the ZR bashing bead method, which can be used for further downstream processing, such as amplification in PCR. Unfortunately, in this laboratory, the Chelex ${ }^{\circledR} 100$ extraction method resulted in much lower PCR amplification than has been previously reported (Châline et al. 2004; Gregory and Rinderer 2004). In addition, contrary to the findings by Châline et

Table III. PCR amplification of DNA extracted by the three different methods and amplified with three different primer pairs.

\begin{tabular}{|c|c|c|c|}
\hline \multirow{2}{*}{$\begin{array}{l}\text { Extraction } \\
\text { method }\end{array}$} & \multicolumn{3}{|l|}{ Primers } \\
\hline & COI-COII $(\%)$ & A113 (\%) & A107 (\%) \\
\hline Chelex $^{\circledR} 100$ & 72 & 60 & 56 \\
\hline Promega & 100 & 88 & 100 \\
\hline ZRBB & 96 & 93 & 100 \\
\hline
\end{tabular}

al. (2004), performing a second round of PCR did not improve the rate of success; the differing magnesium concentrations and annealing temperatures between the two studies may be a cause for this discrepancy. However, the following are possible reasons for these PCR failures:

1. The process of extraction, which includes boiling the samples, could lead to highly denatured DNA.

2. Chelex is a chelating agent which could possibly strip out ions such as magnesium that are essential for a successful PCR amplification.

3. Chelex beads and the components that copurify with the DNA inhibit polymerase enzymes (Steffens and Roy 1998).

4. Chelex-extracted DNA is unstable and degrades even when stored frozen (Griffiths 1996; http://www.bio.net).

The ZRBB DNA extractions resulted in more PCR amplifications than the Chelex ${ }^{\circledR} 100$ extractions. The difference in successful PCR amplifications between the two extraction methods is possibly because the ZRBB method relies upon the physical disruption of the wing tissue, rather than digestion at high temperatures, and does not contain chelating agents or other PCR inhibitors. However, there were still two failed PCR amplifications ( $7 \%$ failed with locus A113). These were not caused by DNA not being extracted from wing tissue, as the same samples were successfully amplified with the other two primer pairs. This variation in amplification of different microsatellite loci has been observed before (Châline et al. 2004; Gregory and Rinderer 2004), although the reason for it is unknown. 


\section{Lane:}

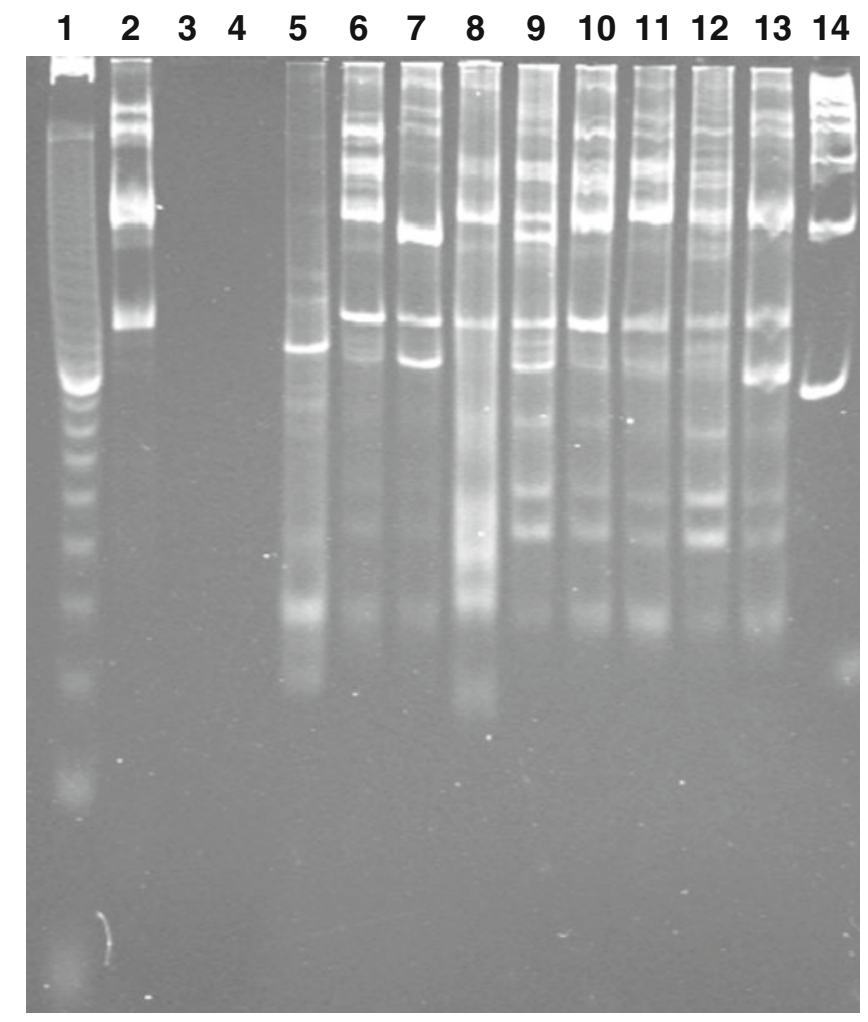

Figure 1. A 6\% PAGE gel of eight bee wings (ZRBB method) plus positive and negative controls amplified with A113. Lanes 1 to 14 are left to right, respectively. Lane layout: 1 10-bp ladder, 2 positive control, 3 master mix negative control, 4 TE buffer negative control, 5 water control, 6 to 13 bee wing samples, 14 100-bp ladder. Note the presence of a bright band and stutter bands in the water sample.

An important point to consider when deciding upon the best method to use is the cost. The Chelex ${ }^{\circledR} 100$ method is cheap, costing NZ $\$ 0.45$ per sample, compared with NZ $\$ 16.50$ per sample for the ZRBB method. Both methods take about the same time, so labour cost is equal. However, the lower cost of the Chelex ${ }^{\circledR}$ 100 method can be offset by the lower subsequent PCR success rate, leading to further extraction or amplification, which will lead to an increase in cost in terms of extraction reagents, PCR reagents and labour. Bearing this in mind, a researcher will have to consider whether data are required from each individual sample, for example in breeding programmes where a higher subsequent PCR success rate is required meaning that the higher material cost is worth paying, or if lower PCR success rate is acceptable, for example in studies investigating genetic variability of bee populations.

The DNA extracted using the ZRBB method would be useful for breeding studies, such as looking for markers of VSH in the queen bee. As the queen is used to produce additional lines, a non-destructive sample is required to enable the breeding programme to continue; thus, samples can only be taken from the queen bee wing. The queen genotype can be compared with the worker and drones within the colony, either using wing samples from the workers or drones or other tissue samples as the workers and drones are more numerous and so some can 
be sacrificed. If studying mitochondrial inheritance, a worker or drone could be used rather than a queen, as mitochondrial DNA is maternally inherited. However, in behavioural studies, microsatellite analysis is used, as the microsatellites are useful markers associated with certain behaviours, such as those displaying Varroa-sensitive hygiene (Harbo and Harris 2005; Harris 2008). Presently, the VSH trait in the queen bee is identified by observing the behaviour of her worker bees. This 14-week process means that VSH queens can only be produced late in the beekeeping season. The accurate identification of genetic markers from the queen wing would enable the queen to be analysed once she has mated ca. 4 weeks, thus enabling the supply of queens to industry throughout the season. In consequence, during a breeding programme, a more reliable method of DNA extraction, such as the ZRBB method, would be required to reduce the risk of subsequent PCR failure, leading to the loss of valuable data.

The presence of bands in the water control samples amplified with the microsatellite primers was confirmed not to be caused by contamination of the primers with DNA or because of the presence of DNA in the polymerase. It is not unusual for bands to appear in water control samples. Primerderived nonspecific PCR products have been found in random amplification of polymorphic DNA PCR amplifications (Pan et al. 1997) and rDNA primers (Böttger 1990). Pan et al. (1997) investigated the cause of the nonspecific products that ranged in size from 100 to $2,000 \mathrm{bp}$ and found that as is the case here, trying new primers did not eliminate the bands and that no bands were present in controls that did not contain either primers or DNA. The authors concluded that these nonspecific bands were from the primers themselves.

In conclusion, we found that the Chelex ${ }^{\circledR}$ 100 method for extracting DNA from bee wings resulted in low PCR amplification success, thus was too inconsistent to be used for further study. The bashing bead method physically broke the wing up and resulted in DNA being extracted from all wing samples, with subsequent PCR amplifications between $93 \%$ and $100 \%$. Therefore, we found the bashing bead method to be more consistent and useful for further research.

\section{ACKNOWLEDGEMENTS}

The authors thank Praveen Nair for his assistance in the laboratory. We also thank Janet Yu for letting us try the ZR bashing bead Bacterial/Fungal DNA extraction kit, which ultimately showed us how this extraction method was superior. The work was funded by Environment Canterbury (contract no. 24954) and the Sustainable Farming Fund (contract no. 24813, sustainable control of $V$. destructor).

Une méthode plus perfectionnée pour extraire et amplifier l'ADN provenant des ailes d'abeilles

ADN / aile d'abeille / PCR / Chelex ${ }^{\circledR} 100$

Eine verbesserte Methode zur Extraktion und Amplifizierung von DNA aus Bienenflügeln

DNA / Bienenflügel / PCR / Mahlkugeln / Chelex ${ }^{\circledR}$ 100

\section{REFERENCES}

Böttger, E.C. (1990) Frequent contamination of Taq polymerase with DNA. Clin. Chem. 36, 1258-1259

Bowen-Walker, P.L., Martin, S.J., Gunn, A. (1999) The transmission of deformed wing virus between honeybees (Apis mellifera L.) by the ectoparasitic mite Varroa jacobsoni Oud. J. Invertebr. Pathol. 73, 101-106

Châline, N., Ratnieks, F.L.W., Raine, N.E., Badcock, N. S., Burke, T. (2004) Non-lethal sampling of honey bee, Apis mellifera, DNA using wing tips. Apidologie 35, 311-318

Franck, P., Coussy, H., Le Conte, Y., Solignac, M., Gaernery, L., Corunet, J.-M. (1999) Microsatellite analysis of sperm admixture in honeybee. Insect Mol. Biol. 8, 419-421

Franck, P., Koeniger, N., Lahner, G., Crewe, R.M., Solignac, M. (2000) Evolution of extreme polyandry: an estimate of mating frequency in two African honeybee subspecies, Apis mellifera monticola and A. m. scutellata. Insectes soc 47, 364-370

Garedew, A., Schmolz, E., Lamprecht, I. (2004) The energy and nutritional demand of the parasitic life of the mite Varroa destructor. Apidologie 35, 419-430 
Gregory, P.G., Rinderer, T.E. (2004) Non-destructive sources of DNA used to genotype honeybee (Apis mellifera) queens. Entomol. Exp. Appl. 111, 173-177

Griffiths S (1996) DNA by Chelex 100 extraction [online methods forum] http://www.bio.net/bionet/ $\mathrm{mm} / \mathrm{methods} / 1996-\mathrm{November} / 052029 . \mathrm{html}$ (accessed 28 October 2010)

Harbo, J.R., Harris, J.W. (2005) Suppressed mite reproduction explained by the behaviour of adult bees. J. Apic. Res. 44, 21-23

Harris, J.W. (2008) Effect of brood type on Varroasensitive hygiene by worker honey bees (Hymenoptera: Apidae). Ann. Entomol. Soc. Am. 101, 1137-1144

Higes, M., Martín-Hernández, R., Botías, C., Baílon, E. G., González-Porto, A.V., Barrios, L., del Nozal, M. J., Bernal, J.L., Jiménez, J.J., Palencia, P.G., Meana, A. (2008) How natural infection by Nosema ceranae causes honeybee colony collapse. Environ. Microbiol. 10, 2659-2669

Pan, Y.-B., Burner, D.M., Ehrlich, K.C., Grisham, M.P., Wei, Q. (1997) Analysis of primer-derived, nonspecific amplification products in RAPD-PCR. Biotechniques 22, 1071-1077

Pérez-Sato, J.A., Châline, N., Martin, S.J., Hughes, W. O.H., Ratnieks, F.L.W. (2009) Multi-level selection for hygienic behaviour in honeybees. Heredity $\mathbf{1 0 2}$, 609-615

Solignac, M., Vautrin, D., Loisaeu, A., Mougel, F., Baudry, E., Estoup, A., Garnery, L., Haberl, M., Cornuet, J.-M. (2003) Five hundred and fifty microsatellite markers for the study of the honeybee (Apis mellifera L.) genome. Mol. Ecol. Notes 3, 307-311

Steffens, D.L., Roy, R. (1998) Sequence analysis of mitochondrial DNA hypervariable regions using infrared fluorescence detection. Biotechniques 24, 1044-1046

Su, S., Albert, S., Zhang, S., Maier, S., Chen, S., Du, H., Tautz, J. (2007) Non-destructive genotyping and genetic variation of fanning in a honey bee colony. $\mathrm{J}$. Insect Physiol. 53, 411-417

Sušnik, S., Kozmus, P., Poklukar, J., Meglic, V. (2004) Molecular characterisation of indigenous Apis mellifera carnica in Slovenia. Apidologie 35, 623-636

Van Engelsdorp, D., Evans, J.D., Saegerman, C., Mullin, C., Haubruge, E., Nguyen, B.K., Frazier, M., Frazier, J., Cox-Foster, D., Chen, Y., Underwood, R., Tarpy, D.R., Pettis, J.S. (2009) Colony collapse disorder: a descriptive study. PLoS ONE 4, e6481

Walsh, P.S., Metzger, D.A., Higuschi, R. (1991) Chelex ${ }^{\circledR} 100$ as a medium for simple extraction of DNA for PCRbased typing from forensic material. Biotechniques 10, 506-513 